\title{
The technology of development of residue ob- jects of precious metals placer deposits
}

\author{
Viktor Litvintsev ${ }^{1 *}$, Vladimir Alekseyev ${ }^{1}$ and Irina Kradenykh $^{1}$ \\ ${ }^{1}$ Mining Institute of Far eastern branch of Russian Academy of Sciences, Khabarovsk, Russia
}

\begin{abstract}
The domestic and foreign experience has been analyzed, showing that the problem of development of geographically close residue goldore deposits was practically not investigated. The necessity of finding new methodological and technological-economic approaches to effective and large-scale integrated management of territorially-contiguous residue placer deposits has been substantiated. A number of methodological provisions for the substantiation of this approach have been proposed, an algorithm and a computer program complex has been developed for calculating the technical and economic indicators for the simultaneous development of each of the geographically approximated residue objects of placer gold deposits. The practice of organization of merger processes in the mining sector of the economy has been analyzed, their features have been examined, the advantages and negative aspects of integration processes have been analyzed, which is an important factor in solving the economic problems of the development of these residue placers. Keywords: residue placer deposits, geographically close alluvial deposits, technologies for the integrated development of residue placers, software complex.
\end{abstract}

\section{INTRODUCTION}

The gold mining industry of Russia remains the most important branch of the economy, including for Far Eastern Federal District (FEFD). At the beginning of the 21st century, the gold mining industry underwent a structural transformation, the extraction of gold from ores (approximately 70\%) began to predominate, whereas only 30\% were extracted from placers, although it was the other way around in the previous century. This has led to a certain crisis in the economic and social spheres in the traditional gold mining regions, caused, basically, by a sharp decrease in the number of operating small and micro-enterprises. The following grouping of mining enterprises for gold production is presented in [1]: large (more than 2 tons), medium ( 0.5 to 2 tons), small ( 0.05 to 0.5 tons) and micro (less than $0.05 \mathrm{t}$ ). At present, the situation began to improve:according to [1] in 2015, compared to 2014, the number of gold mining enterprises in Russia increased by 5\% (475 against 452 in 2014), mainly due to small and micro-enterprises, but the increase in gold production doubled in 10 years ( from 2006 to 2015) occurred due to large organizations only. The extraction of gold by medium, small and micro businesses (especially small business) is practically not growing (table 1).

\footnotetext{
${ }^{*}$ Corresponding author: litvinzev@igd.khv.ru
} 
Table 1. The extraction of gold from placers in 2006-2015, depending on the scale of business

\begin{tabular}{|c|c|c|c|c|c|c|c|c|c|c|}
\hline Scale of & \multicolumn{10}{|c|}{ The volume of gold mining from placers by years, tons } \\
\cline { 2 - 12 } business & 2006 & 2007 & 2007 & 2009 & 2010 & 2011 & 2012 & 2013 & 2014 & 2015 \\
\hline Large & 85 & 97 & 107 & 125 & 130 & 138.6 & 146.1 & 158.7 & 175.4 & 173.7 \\
\hline Average & 25 & 20 & 25 & 21.7 & 16.7 & 20 & 23.4 & 28.3 & 23 & 31.7 \\
\hline Small & 30 & 28.3 & 21.7 & 23.3 & 23.3 & 20 & 26.7 & 31.7 & 30 & 26.7 \\
\hline Micro & \multicolumn{10}{|c|}{ In the range from 3 to 3.2} \\
\hline
\end{tabular}

This once again confirms the fact that in the areas of traditional placer gold mining in Russian Far East, rich and easily accessible placers have been worked out, and small in terms of stocks of metal (including those with sub-standard gold content) are of no interest to subsoil users.

Of course, it is necessary to continue the geological exploration of large placers, but there is already a significant stockpile of gold reserves and other valuable associated components in residue complexes of alluvial deposits. Modern approaches to the development of residue placers are not effective enough, requiring new methods and technological solutions. The direction of our research is aimed at solving this problem.

\section{ANALYSIS OF PROBLEMS}

After working off the geogenous placers, several billion cubic meters of pebble, dredging waste, peat dumps and reloaders from the dumps have accumulated [2]. The annual volume of gold mining from residue placers is about $10-15 \%$ of the extracted metal, which is completely inadequate in conditions of a significant decrease in the reserves and resources of geogenous placers. According to expert data [2], the total amount of gold in all residue placer formations is 5,022 tons or $57 \%$ of the total amount of gold mined in the history of placer exploitation. This convincingly confirms the thesis that residue placers are an important resource of the mineral and raw materials base of placer mining.

B.K. Kavchik and V.G. Pyatakov show that there was gold in each of the spent placers: in some placers - $10-15 \%$ of the mined one, in others - $50 \%$. Despite the low average contents (up to 100-150 mg / m3), almost "... each residue placer has the objects with gold content, which is quite acceptable for profitable extraction" [3]. According to expert estimates, "... ancillary mining from residue and non-traditional sources can provide at least $7-10 \%$ of the total annual all-Russian production" [4].

Only in the Khabarovsk Krai during the period from 2000 to 2007, residue placer complexes of more than 400 million $\mathrm{m} 3$ were formed, characterized by a wide group of chemical elements with a toxic effect. Redisue ore and placer formations lead to a change in the natural landscape, geochemical and geomechanical fields in the rocks, being the bases of the residue massifs, as well as to the change in the hydrological regimes of these areas.

This is a huge environmental burden on the habitat of humans, flora and fauna; therefore the development of these facilities with the subsequent reclamation of disturbed lands is not only of economic but also of social nature.

According to enlarged analytical calculations, gold resources of only 149 residue alluvial deposits of the Khabarovsk Krai total 124.3 tons [5]. These residue placers are distinguished by ordinary and low metal content, calculated on the entire processed rock mass of the deposit. Residual gold is concentrated mainly in dredging waste; therefore, one should expect an actual increase in the metal content in them by 2-3 times (depending on the ratio of dredging waste and gravel fractions in the dump complex).

The results of many studies allow drawing the following conclusions: 
a) Single processing of natural placer does not allow to extract gold completely, its losses were significant. The amount of abandoned metal (rafts, side and residual tiles) or sands lost during washing (dredging waste and pebble dumps, mud) reaches 10 to $150 \%$ or more of its volume in the primary placer [3, 6-8];

b) Repeated mining of residue placers exacerbates the impact on the environment, expanding the range and severity of environmental problems, so the full and integrated extraction of useful components will allow the territory to be cleaned of harmful substances and recultivated.

The results of the planned studies are a scientific and technological basis for large-scale involvement in the operation of complex resources of residue objects minerals various in terms of rock mass volumes. However, a special approach is required to solve this problem. We propose a new strategic approach to the integrated development of residue placers - the development of geographically close residue placers with the processing of rock mass on a stationary washing device (dressing plant).

All the factors listed above show that the creation of scientific and methodological foundations of technology for the development of geographically close residue placers is an actual fundamental and applied task aimed at addressing, among other things, the socioeconomic and environmental problems of the region.

There is no exact analogue of the proposed line of research with respect to residue placers, but there are a number of related studies on the development of ore and placer deposits and methodological approaches to the organization of processing their rock mass.

On the example of sub-standard ores, which at present cannot be economically worked out as an independent raw material, Academician K.N. Trubetskoy reveals the possibilities of resource-reproducing functions of mining production by changing the conditions for the occurrence of the dredge in question: "With their indirect development by open method and separate stockpiling on the surface or in the formation of residue deposits with optimal parameters, they become a real resource, and their reserves can be developed with profit" [9].

This approach is certainly relevant for solving the problem of large-scale and complex development of residue placers.

Among the technical solutions close to the planned research, other technical solutions are known, both in Russia and abroad.

The thesis of V.R. Kabirov "Assessment of the economic efficiency of the development of a group of geographically-related ore (metal) deposits" lists the following stages of development of such deposits: 1 - Consideration of a group of geographically-adjacent deposits from the standpoint of technological possibilities for their development; 2 - Identify the possibilities of creating common links of infrastructure for a group of geographically adjacent deposits; 3 - Selection of a variant for the development of geographically adjacent deposits; 4 - Determination of the sequence of involvement of each field in the development [10]. The peculiarity of this research is that a single infrastructure base is formed taking into account the definition of the optimal location and the number of processing complexes.

In [11], D.S. Opryshko provides a rationale for a rational technology for the development of small continental placer gold deposits. The result of the study is the substantiation of the solution of the issue of effective technical and technological possibility of involving small gold-bearing placers, including residue ones that are currently unprofitable in the operation, by using the existing small-sized machinery and the improvement thereof, in relation to specific mining-geological and climatic conditions. This is an important aspect that must be taken into account when developing approximate placers.

The authors of [12] theoretically deeply substantiated the methods of estimating the increment and quality of reserves of approximate placers within a single river valley, where, along with available placers, exist the low-margin ones, which are often never involved in development, although, as practice shows, they are licensed by a single mining enterprise. 
In some cases, the joint development of such placers may prove to be economically viable, and the active part of the mineral-raw-material base of placer gold can be substantially expanded. The resulting availability of the entire valley's reserves is determined by the availability of the base field, while the sequence of commissioning of other fields is consistent, determined by the subsoil user. This is one of the principal differences from the technology developed by us.

There is a well-known rationale for the expediency and order of commissioning of a group of kimberlite quarries that are part of the MIBA mining company (Democratic Republic of the Congo), taking into account the creation of a sustainable schedule of overburden for each of the quarry groups, as well as minimizing transportation costs for supplying several concentrator factories [13]

In the thesis, A.B. Anisimova implements the idea of the possibility of replenishing the mineral and raw materials base of solid minerals with the use of methods for the economic evaluation of the effective development of similar deposits of unallocated and unaccounted subsoil fund [14].

The analysis of domestic and foreign experience shows that the problem of developing geographically close residue placers has not been fully explored, therefore the planned study is important from both scientific positions, and from technological, economic and environmental ones.

Residue placers have features that differ from the pillar placers. These are: lower gold content (not always!); its granulometric features, expressed in the predominance of fine fractions; a significant dispersion of volumes of rock masses, depending on the methods of the primary placer mining; spatial disconnectedness of residue products promising for processing; good rinsing of residue formations, determined by the granulometric homogeneity of the material of the dumps; various degree of safety of residue formations in the modern relief, etc. In earlier studies $[15,16]$, the features of the resource potential of residue goldore deposits characterized by the effect of their renewability under the influence of natural processes have been noted, and new technological directions for the development of residue complexes of alluvial deposits have been proposed.

It is necessary to note especially the presence of other associated components of value in the sands, which, on the one hand, makes their exploitation difficult, and on the other hand, can increase their economic attractiveness [9]. Associated components of goldbearing placers can be of considerable significance and used in various spheres of the national economy. The dumps of residue complexes of placers contain rare earth minerals suitable for the production of composites, high-magnetite sands - for further processing with the obtaining of products for the production of paints or iron ore, the rock mass of thin clay dredging waste heaps can be used as a material for road construction as gravel. Only in the Khabarovsk Krai, in addition to the balance gold-platinum complex placer deposits, dozens of reside alluvial gold deposits containing cassiterite, wolframite, magnetite, ilmenite, and rare earth elements are available.

\section{METHODS AND DIRECTIONS OF RESEARCH}

All of the above allows concluding that it is necessary to search for new methodological and technological and economic approaches to solving the problem of effective and largescale integrated development of geographically close residue placers.

Currently, we have determined the number of methodological provisions for the substantiation of this approach, an algorithm has been created and a software package for a computer has been developed to calculate the technical and economic indicators for the simultaneous development of several selected placer-related residue objects of several placers, transporting it to a special site, processing the delivered rock mass on a stationary 
flushing device or dressing plant). The selection of the location of the stationary industrial device (dressing plant) is determined by the software complex, provided transportation and operating costs are minimized [17].

The sequence of acceptance of methodical, project-technological and financialeconomic solutions for the development of a number of closely related residue placer sites includes the following stages:

1. The mining and geological parameters of geographically close residue placers of a particular region, the resources of the base metal and valuable passing components are determined by satellite imagery or, if available, based on the design and engineering documentation of the worked out geogenous placers.

2. If a license is available and the selected fields are included in the list of developed fields, a full range of geological exploration is carried out at all fields, or exploration work is carried out in the course of actual mining in order to clarify the complex resources of the fields.

3. The type of washing device (dressing plant) equipped with additional dressing equipment is chosen, its productivity is calculated. With the help of the developed software package, a sustainable (by economic, technological and ecological indicators) location of a stationary flushing device is determined. A procedure is being developed for the preparation of the stockpiled rock mass on a special site near the flushing device and its subsequent processing, provided that the reserves of all deposits are uniformly offset for the planning period set.

Let's consider in more detail the operation of the software.

Matlab R2013b has been selected to compile a mathematical model of the mining area. The selected mathematical package is well optimized for working with the matrix data type. The Matlab core allows you to easily and quickly work with matrices, which is an important factor for large amounts of data.

The main idea in creating a mathematical model is to break up the study area into elementary areas of a given size and to represent the resulting set of elementary sites and the entire territory as a whole into a matrix view.

To form a matrix representing the area under investigation, we use the developed application, implemented in $\mathrm{C}++$, using the Visual Studio 2013 software environment.

The investigated territory is divided into a matrix of a given size, where each element of the matrix is an elementary site of the terrain. An identifier is assigned to each site, defined by the program logic, depending on the type of site. When forming the matrix form of the investigated territory, the elementary parts of the terrain are divided into several types:

- accessible parts of the terrain - areas where the dressing plant can be located, and through which the route from the field to the plant can be laid, the identifier of section 1;

- inaccessible areas of the terrain - areas where it is impossible to locate the dressing plant and the route (elevations, ponds), site identifier 0 ;

- deposits - places where the rock is exported to the dressing plant, an identifier of the site 4;

- the proposed optimal location of the dressing plant, the site identifier 3;

- the route from field to plant, the site identifier 2.

The relevant areas are noted in the application that forms the matrix. The remaining sections are marked as available ones. The optimum location of the dressing plant and the routes from the fields to the plant are determined during the calculation of the mathematical model.

To determine the distance from the deposits to the prospective location of the dressing plant, an algorithm for finding the shortest path has been developed. The beginning of the algorithm operation is that starting from the selected elementary section, where the deposit is located, the distance from adjacent accessible elementary sites to the proposed location of 
the factory is calculated. Neighboring sites are classified in the sense of Moore's neighborhood, where all eight sites are considered to be neighboring. Unavailable sites, if any, are excluded from the calculation.

From the distance values obtained, the smallest is chosen; the segment with the smallest distance is defined as the route to be laid. The following calculation is made between the neighboring sections with the previous elementary sections obtained during the last calculation by the route laid. A site with the shortest distance to the proposed location of the plant becomes the next point on the route. The calculation is made before reaching the final section.

To determine the optimal location of the industrial device or dressing plant, a cell is selected that is accessible at the beginning of the matrix map and is marked as a cell on which the dressing plant is located. The program determines the shortest routes from the deposits to the prospective site of the dressing plant, then, based on the initial data on the fields and the transport and mining equipment used, calculates the profitability of the plant when it is placed in the specified cell. After that, the next available cell is selected, for which, on the same principle, the profitability of the plant is determined when it is placed in a new cell. Thus, all available cells are calculated. After calculation, the cell with the maximum profitability index is selected. The resulting cell on the plan is the most optimal location for the dressing plant.

Thus, a software method has been developed for determining the optimum location of the flushing device or dressing plant for effective development of the adjacent residue placers or adjacent small (possibly unprofitable) natural placers.

The proposed approach will require subsoil users to attract significant financial resources, use modern and efficient mining and processing equipment, therefore, mostly small and medium-sized enterprises in the extraction of metals may need a restructuring of their structure through, for example, horizontal integration. This is a real opportunity to carry out the large-scale development of residue placers with high efficiency even with minimal conditional contents of useful components.

\section{CONCLUSIONS}

An analysis of domestic and foreign experience in the study of the problems of the development of natural and residue placers shows that the strategic issues of developing geographically close residue gold-ore deposits have been poorly studied, but the importance of their solution, in conditions of a decrease in the level of placer gold mining, is increasing.

The search for new methodological and technological-economic approaches to solving the problem of effective and large-scale integrated development of geographically close residue placers is an important fundamental and applied task.

A number of methodological provisions for the substantiation of this approach as well as an algorithm and a software complex for computation of technical and economic indicators for the simultaneous development of each of the geographically approximated residue objects of gold-ore deposits have been developed.

The practice of organization of merger processes in the mining sector of the economy has been analyzed, their features have been examined, advantages and negative aspects of integration processes have been analyzed, which is an important factor in solving economic problems in the development of residue placers.

The most important result of the introduction of this technology will also be a significant increase in the social and environmental safety of the regions of traditional placer gold mining. 


\section{References}

1. Goldmining Union Analytical review "Gold of Russia 2015", - access link: http://goldminingunion.ru/news/view/3667.htm

2. B.I. Benevolskii, T.P. Shevtsov, Concerning the potential of residue gold placers in the Russian Federation // Mineral Resources. 1. P. 9-16. (2000)

3. B.K. Kavchik, V.G. Piatakov. Zolotodobycha. 135. pp. 14-19. (2010).

4. S.V. Belov. Zolotodobyvayushchaya promyshlennost'. 3 (27). pp. 30-37. (2008).

5. A.P. Van-Van-E, Resource base of natural-residue gold-ore deposits "Gornaya Kniga" publishing house, Publishing house of Moscow State Mining University. pp 268. (2010).

6. Iu.A. Mamaev, A.P. Van-Van-Ye, A.P. Sorokin, V.S. Litvintsev, A.M. Puliaevskii, Problems of rational development of gold-ore deposits of Far East. (geology, mining, processing) / Vladivostok: Dalnauka. pp 200. (2002).

7. L.Z. Bykhovskii, L.V. Sporykhina, K.V. Tsvetkova. Placers and deposits of residue, current problems of study and development. Material of XIV International conference, Novosibirsk: Apelsin. pp. 141-148. (2010).

8. Z.G. Mirzekhanova, G.S. Mirzekhanov, I.D. Debelaia Residue formations of placer gold deposits: resource and technological aspects of mining. Khabarovsk, FED RAS. pp 297. (2014).

9. K.N. Trubetskoi. Mining magazine. 11. pp. 18-23. (2009).

10. V.R. Kabirov, E.I. Reishakhrit. Proceedings of the $11^{\text {th }}$ International Scientific and Practical Conference "Development of Mineral Resources of the North: Problems and Solutions". Vorkuta city: Vorkuta Mining Institute (division) FGBOU HPE "Gornyi" National Mineral and Raw University. pp. 545-548. (2013).

11. D.S. Opryshko. Collection: New ideas in sciences of earth. Moscow. 2. pp: 81. (2005).

12. M. Kh. Peshkova, N. A. Matsko, M. iu. Kharitonova. Mining informationanalytical bulletin. MGGU. 10. pp. 29-36. (2007).

13. Bukasa Mukendi Pitchu, Abstract of a thesis for PhD in Technical Sciences degree majoring in 25.00.21 "Justification of the expediency and priority of the development of the Bakwang diamond core deposits by a group of quarries", link: http://www.dissercat.com/content/obosnovanie-tselesoobraznosti-i-ocherednosti-razrabotkikorennykh-mestorozhdenii-almazov-bak\#ixzz4K61OONAL

14. A.B. Anisimova. The economic justification for involving the development of the adjacent iron ore deposits of the polar Urals // Abstract of a thesis for PhD in Economic Sciences degree, M.: FSBEI HPE " Russian State Geological Prospecting University". p. 24 (2011).

15. V.S. Litvintsev. Physical and technical problems of mineral development / Novosibirsk, Siberian Division of Russian Academy of Sciences. 1. pp. 118 -126. (2013).

16. V.S. Litvintsev. "Physical and technical problems of mineral mining" magazine. 1. pp. 97 - 104. (2015).

17. Certificate of state registration of the computer program No.2016619240 "Program for the search for the optimal location of the concentrator in the development of geographically-adjacent mineral deposits", the date of state registration in the Register of Computer Programs - August 16, 2016. Authors: V.S. Litvintsev, A.A. Sokol, V.S. Alekseyev, I.A. Kradenykh. 